The fly oviposits, in my experience, largely at night, though the observations made under Prof. Riley's direction prove that many are also laid during the day. Flies in captivity always oviposited for me at night only. I never was able to see in the field a single fly on fresh droppings during the day, while eggs were easily found on these one day old. No

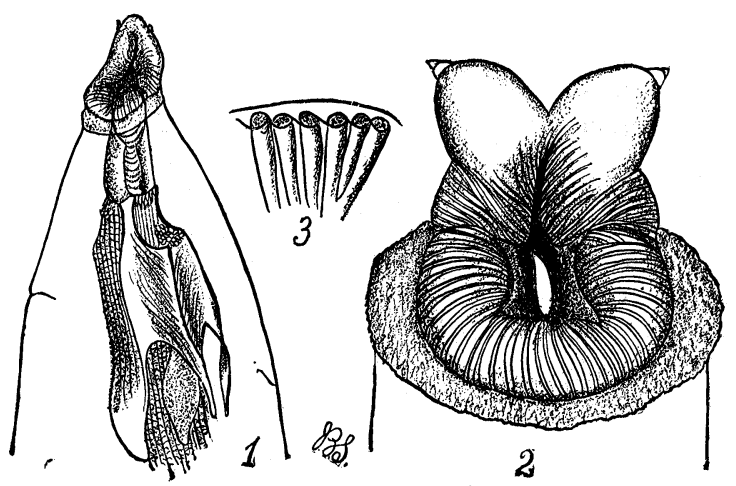

FIG. 6. amount of negative result can counterbalance positive observation, but I still believe that eggs are largely laid at night, in New Jersey at least. Observations made by Mr. Bodee of Freehold are confirmatory of this view. 'The fly hibernates in the imago state, and in a winter like the one just past, breeds nearly all the time, remaining quiet in stables and wherever it finds shelter only in really cold weather. Dr. Lockwood bred the flies in February from droppings brought in from the fields.

It is a rather curious phase in the history of this fly that up to the beginning of August it seems to increase enormously, fairly swarming about the cattle, - worst perhaps in June and early July, - while they are scarcely

annoying after the middle of August and hardly as abundant as Stomoxys. It seems also that early in the year they congregate about the base of the horns of cattle much more than they do later in the season.

Fig. 1. $a$, Tip of opercular sheath; $b$, a single sucker disc; $c$, tip of canula; $d$, tip of hypopharynx: all enlarged.

Fig. 2. a, Palpus - The corresponding organ of the opposite side is omitted; $b$, the "great tendons"; $c$, throat; $d$, muscular bands to direct the proboscis; $e$, base of canula; $f$, base of opercular sheath shoving ringed structure and tactile hairs; $g$, the fulcrum: enlarged.

Fig. 3. $a$, Alar appendix; $b$, piece of wing; $c$, piece of trunk vein; $d$, piece of transverse or auxilliary vein: enlarged.

Fig. 4. Oviduct of female: enlarged.

Fig. 5. Genitalia of male: enlarged.

Fig. $6 . I$, Head and anterior segment of larva showing structure of pumping stomach; 2, mouth, further enlarged; 3, tubes of lip still further enlarged.

\section{NOTES ON THE SOUTHERN DISTRI- BUTION OF SOME COMMON BUTTERFLIES}

There seems to be a little uncertainty as to the proper Southern range of some of our otherwise well-known butterflies, and so possibly the following notes, though coming from only a linited locality, may help to add a link in the chain of life history of our lepidoptera.

Chrysophanus hypophlatas: In the month of August I889, I found this fairly abundant in the neighborhood of Caesar's Ilead, S. C. These agree with New Jerse: 
examples in my collection. I found them along roadsides bordering fields, and sometimes in the wet sandy roads where mountain streams crossed. In Columbia, S. C., this past autumn, I found $C$. hypophlaeas quite common, frequenting the open meadows and weedy fields, and appearing fiequently on the college campus. They presented the same quich nervous flight that I have observed in the species elsewhere and which is characteristic of the Theclas rather than our forms of Lycaena. My first acquaintance with them here was in October, and they continued abundant until late in December. They were on the wing late in February, apparently a fresh brood, and during March were quite plentiful. As yet, however (8 April) there seems to be but the one brood, the unseasonably cold weather in March having doubtless affected thern. I am unable to give any information about the number of broods. I have never seen it near Charleston.

Neonympha canthus: This species is given by all authors as northein and western.

While collecting Catocalas in September, $\mathbf{r 8 8 9}$, in a thick swamp in Clarendon county, S. C., near the Santee River, I came to a spot where a ray of sunlight, penetrated the thick foliage far overhead; and there, in the glow, were a great number of the Wood Ringlet, Debis portlandia, having a game of "Toucher," or "Hide-and-seek" with one another. I stood watching their gambols for some time, until I thought that one of their number seemed smaller and otherwise different from the rest; in a moment he lit close to me, and I saw to my surprise, that it was something entirely different, and at the moment I could not place it. That was enough however, and I started to capture it; but the game was not in my own hands; at the first movement, off he went jerking in and out among the cypress knees and live oak buttresses for some distance, and becoming invisible when he lit. Capture on the wing seemed the only possible means of securing him, and so off I dashed, into tree-trunks, splashing through water and occasionally falling flat in the mud, over a concealed root, but the last time I fell, my net was over my prize, which proved to be Neonympha canthus; after considerable beating about, I started another, whose final capture was effected after a repetition of $m y$ first chase.

These were the only two seen, though I hunted the same swamp for the next day. An early departure prevented further search. This capture seemed strange, for that especial swamp has been a favorite hunting ground of mine for over eight years, and has been searched thoroughly by me.

These two are much darker, and of a gray rather than a brown tint, when compared with Maine examples in my collection, and also with $\mathrm{Mr}$. Scudder's admirable figure. This is the only instance to my knowledge, of the occurrence of the species anywhere in the southeastern states.

Ellison A. Smyth, Fr., Columbia, S. C.

The genus Argynnis. The reprint (Psyche v. 5, p. 308-317) of Mr. H. J. Elwes's observations on the North American Argynnides did not include the table of synonyms, list of localities and other interesting matter. Mr. Elwes will be glad to send a separate of his paper to anyone desiring to study his views more fully than can be done from the reprint in Psyche. His address is Preston House, Cirencester, England.

Habit of Vespa. In Psyche v. 5, p. 54, Mr. J. H. Emerton figures a wasp, apparently Vespa maculata, hanging by one leg devouring a fly. When I read his account, I could hardly believe that so singular a position could be usual, and was therefore much interested in observing the same thing here in Colorado last year. On 24 August, near Willow Creek, Custer Co., Col., I found a Vespa maculata devouring a fly in exactly the same attitude as figured by Mr. Emerton. It was hanging from the edge of the roof of a house.

T. D. A. Cockerell, West Cliff, Col. 

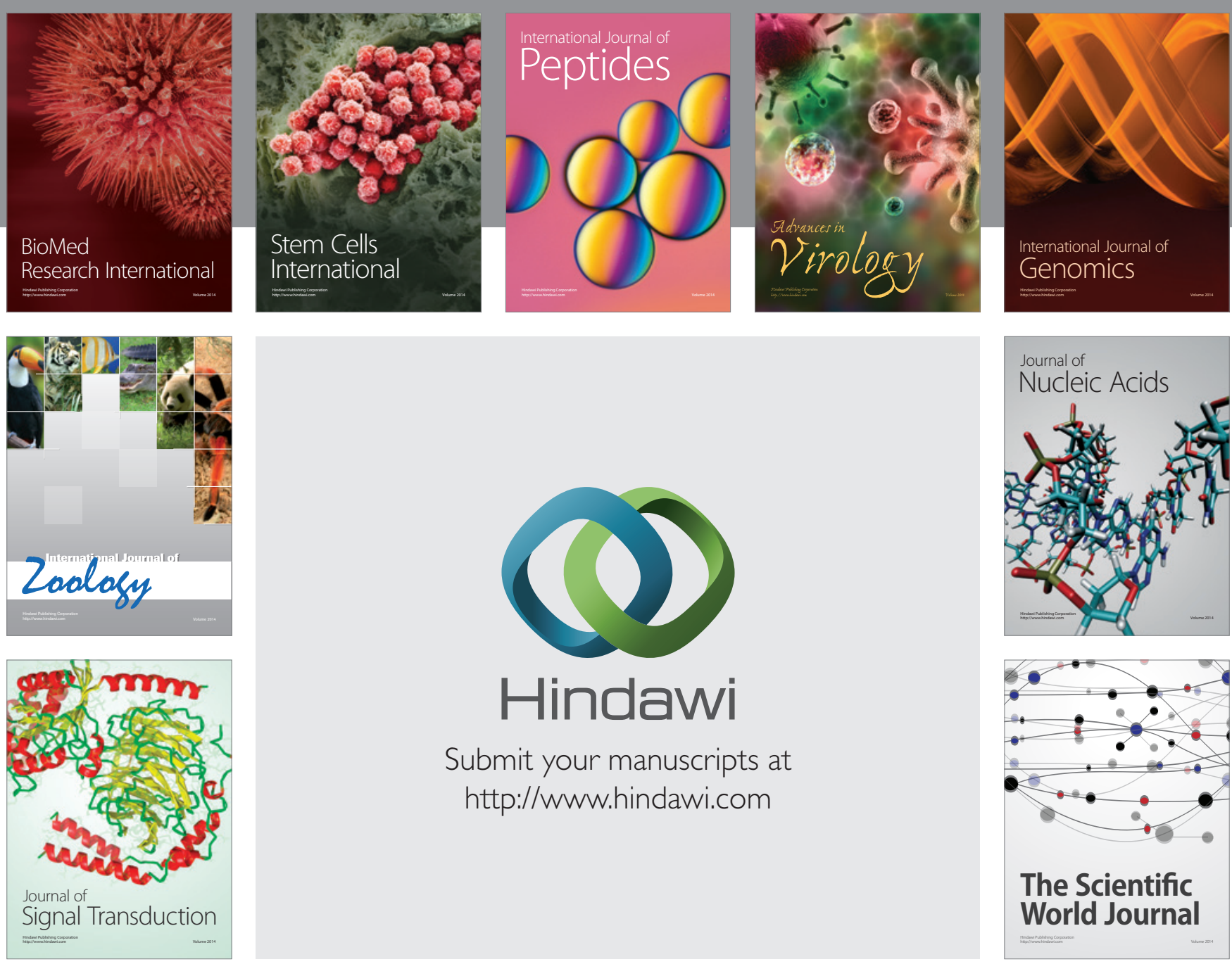

Submit your manuscripts at

http://www.hindawi.com
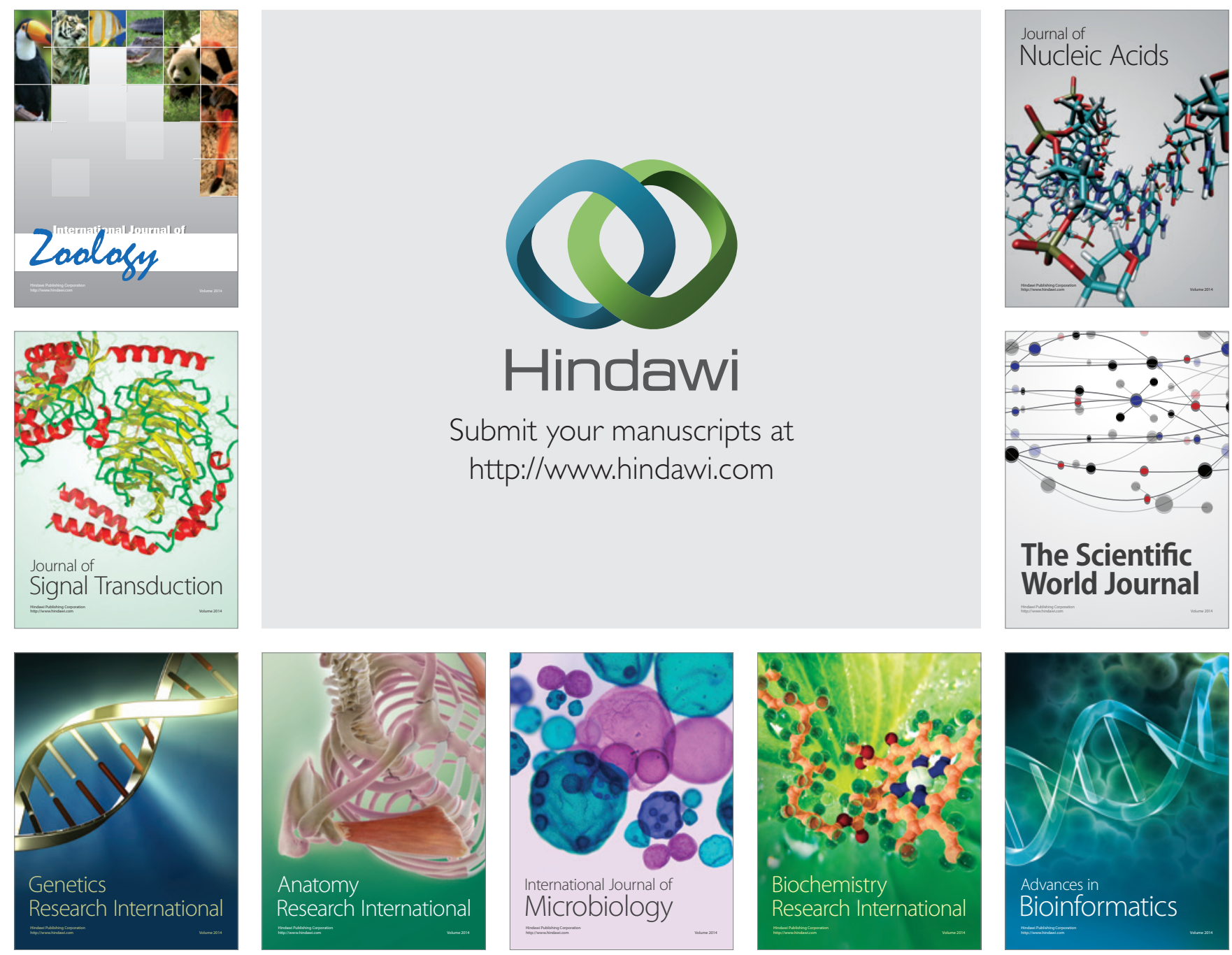

The Scientific World Journal
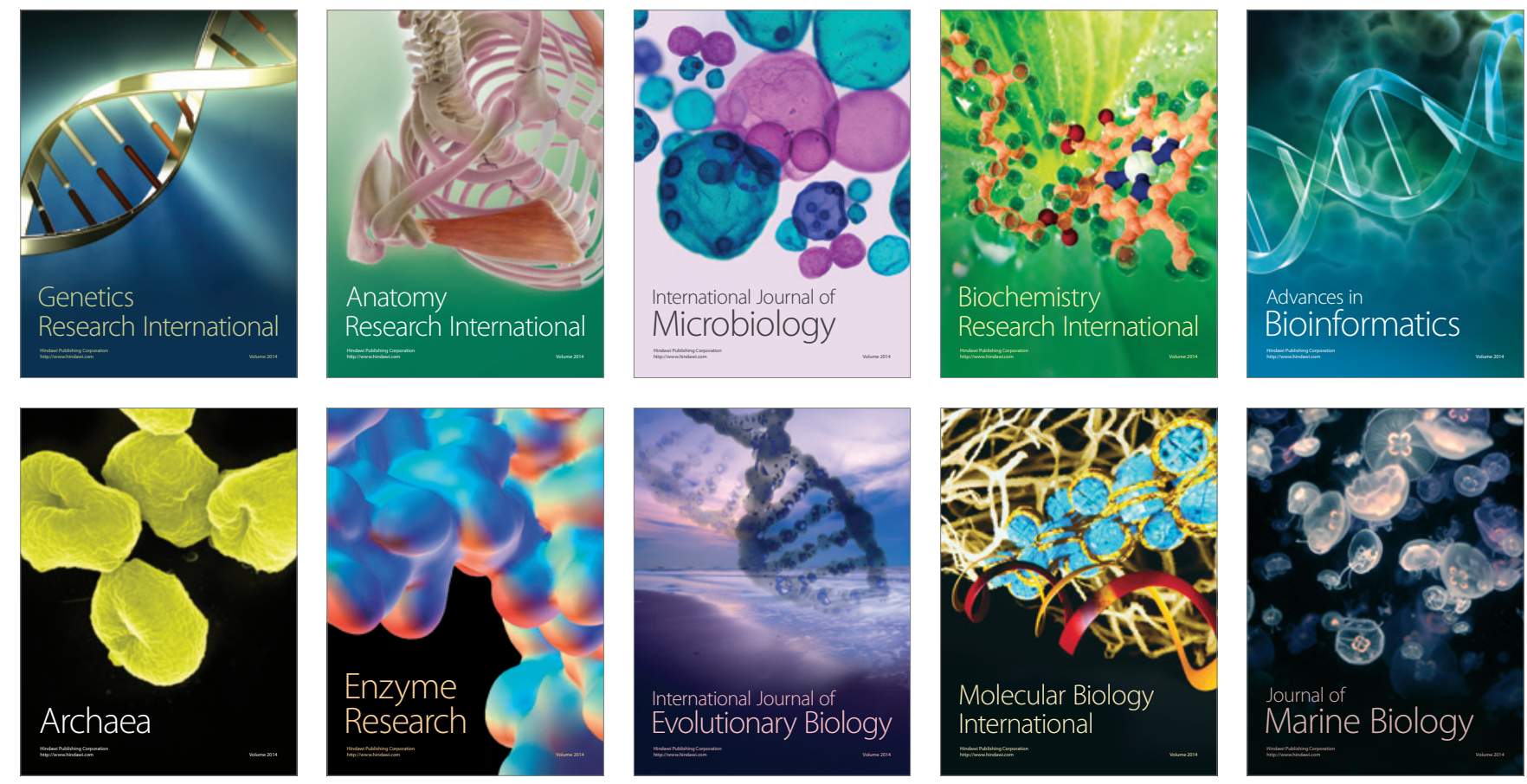